
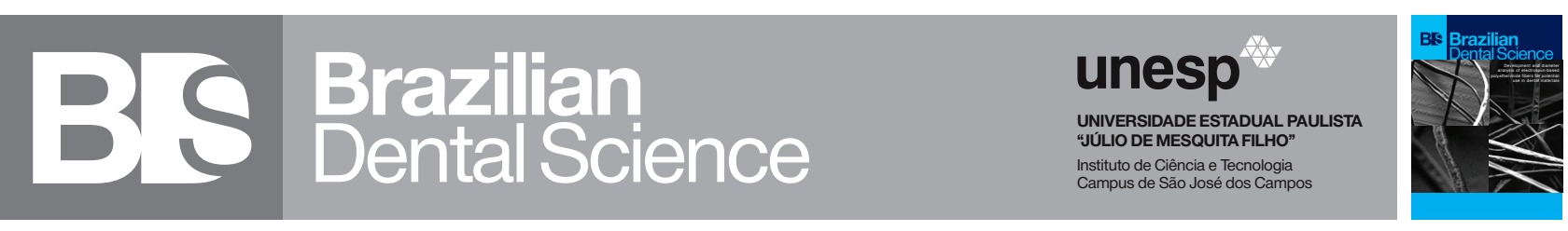

\title{
Effect Of Chitosan Treatment On Shear Bond Strength Of Composite To Deep Dentin Using Self-Etch And Total-Etch Adhesive Systems
}

Efeito do tratamento com quitosana na resistência ao cisalhamento de resina composta em dentina profunda usando sistemas adesivos autocondicionantes e condicionamento total

Fateme VASEI ${ }^{1}$, Farahnaz SHARAFEDDIN ${ }^{2}$

1 - Department of Operative Dentistry, School of Dentistry, Shiraz University of Medical Sciences, Shiraz, Iran.

2 - Department of Operative Dentistry, Biomaterials Research Center, School of Dentistry, Shiraz University of Medical Sciences, Shiraz, Iran.

\begin{abstract}
Objective: To assess the shear bond strength (SBS) of resin composite to deep dentin, using 1 and 2.5\% chitosan pretreatment as well as different adhesive systems. Material and Methods: 80 human maxillary molars were randomly divided to eight groups according to the type of adhesive system and dentin pretreatment $(\mathrm{n}=10)$ : I) two-step self-etch system (Clearfil SE bond); II) two-step etch-andrinse system (Adper single bond 2); III) 2.5\% chitosan + Clearfil SE bond; IV) $2.5 \%$ chitosan + etch + Adper single bond $2 ; \mathrm{V}$ ) etch $+2.5 \%$ chitosan + Adper single bond 2; VI) $1 \%$ chitosan + Clearfil SE bond; VII) $1 \%$ chitosan + etch + Adper single bond 2; VIII) etch $+1 \%$ chitosan + Adper single bond 2 (chitosan solution (w/v): $2.5 \mathrm{~g}$ and 1 $\mathrm{g}$ of chitosan (Sigma Aldrich, USA) was dissolved in 100 $\mathrm{ml}$ of $1 \%$ acetic acid). Plastic molds were positioned on dentin and filled with composite (Z350, 3M ESPE, USA). SBS (MPa) was tested using a universal testing machine. ANOVA tests, Tukey's test, and independent $t$ test were used to analyze data ( $\mathrm{p} \leq 0.05$ ). Results: The highest SBS value among self-etch groups was observed with $1 \%$ chitosan $(\mathrm{p}=0.001)$. In the etch-and-rinse group, the SBS of $1 \%$ chitosan was significantly lower than the other groups. Chitosan treatment following acid etching led to higher SBS in comparison to when chitosan was applied before etching, with the significant difference in $1 \%$ concentration $(p=0.030)$. A predominance of mix fractures was observed in dentin. Conclusion: Improved dentin bond strength can be achieved through immediate dentin pretreatment with $1 \%$ chitosan in self-etch adhesive systems. Chitosan Pretreatment may not be advantageous for etch-and-rinse adhesive systems.
\end{abstract}

\section{KEYWORDS}

Adhesive system; Chitosan; Deep dentin; Shear strength.

\section{RESUIMO}

Objetivo: Avaliar a resistência ao cisalhamento (RC) da resina composta em dentina profunda, utilizando quitosana de 1 e $2,5 \%$ como pré-tratamento, e também diferentes sistemas adesivos. Materiai e métodos: 80 molares superiores humanos foram divididos aleatoriamente em oito grupos de acordo com o tipo de sistema adesivo e pré-tratamento dentinário ( $\mathrm{n}=10)$ : I) sistema autocondicionante de dois passos (Clearfil SE bond); II) sistema convencional de dois passos (Adper Single Bond II); III) quitosana 2,5\% + Clearfil SE bond; IV) quitosana 2,5\% + ácido + Adper single bond; V) ácido + quitosana 2,5\% + Adper single bond II; VI) quitosana 1\% + Clearfil SE bond; VII) quitosana 1\% + ácido + Adper single bond II; VIII) ácido + quitosana 1\% + Adper single bond II (solução de quitosana (w/w): 2,5 ge $1 \mathrm{~g}$ de quitosana (Sigma Aldrich, EUA) foi dissolvido em $100 \mathrm{ml}$ de ácido acético a 1\%). Moldeiras foram posicionados na dentina e preenchidos com resina composta (Z350, 3M ESPE, EUA). O RC (MPa) foi testado em uma máquina de teste universal. Os testes ANOVA, teste de Tukey e teste $\mathrm{t}$ foram usados para analisar os dados ( $\mathrm{p} \leq 0,05)$. Resultados: O maior valor de RC entre os grupos autocondicionantes foi observado com quitosana a $1 \%(\mathrm{p}=0,001)$. No grupo do condicionamento total a RC da quitosana a $1 \%$ foi significativamente menor do que nos outros grupos. O tratamento com quitosana após o condicionamento ácido levou a um maior RC em comparação a quitosana aplicada antes do condicionamento, com diferença significativa na concentração de $1 \%(\mathrm{P}=0,030)$. Observou-se predomínio de fraturas na dentina. Conclusão: A resistência de união à dentina pode ser alcançada por meio do prétratamento imediato da dentina com quitosana a $1 \%$ em sistemas adesivos autocondicionantes. O pré-tratamento com quitosana pode não ser vantajoso para sistemas adesivos de condicionamento total.

\section{PALAVRAS-CHAVE}

Sistema adesivo; Quitosana; dentina profunda; força de cisalhamento. 


\section{INTRODUCTION}

$\mathrm{T}$ he main restraint of resin-based restorative materials is the longevity of adhesive systems in these restorations. The endurance and strength of the bond between the tooth structure and composite resin remain as the key factors in durability of composite resin restorations. The stability of the bonded region over time is affected by the creation of a homogeneous and stable hybrid layer [1].

Dentin bonds are much greater challenge compared to enamel bonds [2]. Due to degeneration of hybrid layer at the resin-dentin interface, a decrease in the bond strength of resin to dentin transpires over time [3]. Particularly, the struggle is greater in deep dentin owing to the reduced inter-tubular dentin and enlarged tubular diameter [4].

A classification of adhesive systems can be grounded in their etching technique: total-etch (etch and rinse) and self-etch adhesives [5]. Greater bond strength values have been reported for the total-etch adhesive system compared to self-etch adhesives [6, 7]. However, both preliminary etch-and-rinse adhesives and the less potent self-etching adhesives can activate matrix metalloproteinases (MMPs) throughout the dentin bonding process which degrade the unprotected collagen fibrils [8], resulting in a reduced bond durability [9]. Several studies investigated various inter- and intra-molecular crosslinking in order to stabilize the collagen Dbrils. These efforts were made with the aim to minimize the enzymatic degradation and to generate a more effective dentin collagen substrate [10]. In this regard, surface treatment with a substance which can inhibit MMPs can play an imperative role in preserving bond strength over time [11].

Surface treatment with chitosan, which is a biopolyaminosaccharide derived from alkaline deacetylation of chitin, has shown resistance against degradation by bacterial collagenase [12]. Chitosan has numerous favorable properties such as biocompatibility, biodegradation, mucoadhesion and broad- spectrum antibacterial properties against Grampositive and Gram-negative bacteria [13,14]. In dentistry, chitosan has been used as a caries prophylaxis agent [15] and wound healing agent in bone / periodontal tissue remodeling [16]. The antibacterial mechanism of chitosan is due to interaction between the positive (cationic) charge of the chitosan amino groups with the negative (anionic) membrane of bacteria [17]. Moreover, Szczepanska et al. [18] showed that low concentrations of chitosan (up to 0.5\%) increases pulp protection.

Several previous studies reported adverse effects of chitosan incorporation on the bond stability of adhesives. Elsaka [19] reported that while $0.12 \%$ and $0.25 \%$ chitosan had no influence on the bond strength, higher concentrations resulted in reduced bond strength values. Additionally, another study confirmed a compromised bond strength to dentin when chitosan was applied with the experimental etch-and-rinse two-step adhesive system [18].

Although some previous studies have shown the adverse effects of chitosan incorporation to adhesives on the bond strength of resin composite to dentin surfaces, there is no previous literature on the effect of various concentrations of chitosan pretreatment on the shear bond strength of resin composite to deep dentin. Given the proven inhibitory effects of chitosan on MMPs and the importance of the bonding process in the success of composite restorations, the objective of the present research was to investigate the effect of different concentrations (1 and 2.5\%) of chitosan treatment on SBS of composite to deep dentin using self-etch and etch-and-rinse adhesive systems.

\section{MATERIAL AND METHOD}

The study was approved by SUMS ethics committee (IR.SUMS.Dental.Rec.1398.112). Table 1 shows the description of materials applied in this research. 
Table I - Sample grouping

\begin{tabular}{|c|c|c|c|}
\hline Material & Manufacturer & Composition & Lotnumber \\
\hline Filtek $^{\text {TM }} \mathrm{Z} 350 \mathrm{XT}$ & 3MESPE,USA & $\begin{array}{l}\text { Resin Matrix: Bis-GMA, UDMA, TEGDMA, Dimethacrylate } \\
\text { Filler content: } 78.5 \text { wt\% (59.5 vol\%) Silica, zirconia, aggregated zirconia/silica }\end{array}$ & N856842/N824377 \\
\hline $\begin{array}{l}\text { Adper Single } \\
\text { Bond 2 }\end{array}$ & 3MESPE, USA & $\begin{array}{l}\text { HEMA, bis-GMA, ethyl alcohol, silane-treated silica (nanofiller), glycerol 1,3-di- } \\
\text { methacrylate, copolymer of acrylic and itaconic acids, diurethane dimetha- } \\
\text { crylate, water, } 10 \% \text { by weight of silica nanoparticles }\end{array}$ & NA42813 \\
\hline Clearfil SE Bond 2 & Kuraray Co Ltd, Osaka, Japan & $\begin{array}{l}\text { Primer: HEMA, hydrophilic dimethacrylate, MDP, N, N-diethanol p-toluidine, } \\
\text { camphorquinone, water } \\
\text { Adhesive: Bis-GMA, HEMA, hydrophobic dimethacrylate,MDP, camphorquino- } \\
\text { ne, N, N-diethanol-p-toluidine, silanized colloidal silica }\end{array}$ & $960426 / 940266$ \\
\hline 1\% Chitosan & Sigma Aldrich, USA & $\begin{array}{l}1 \mathrm{~g} \text { of low molecular weight chitosan (75-85\% deacetylation) was dissolved in } \\
\qquad 100 \mathrm{~mL} \text { of } 1 \% \text { acetic acid }\end{array}$ & SLBJ5775V \\
\hline 2.5\% Chitosan & Sigma Aldrich, USA & $\begin{array}{l}2.5 \mathrm{~g} \text { of low molecular weight chitosan ( } 75-85 \% \text { deacetylation) was dissolved } \\
\text { in } 100 \mathrm{~mL} \text { of } 1 \% \text { acetic acid }\end{array}$ & SLBJ5775V \\
\hline
\end{tabular}

In this experimental study, a total of 80 human maxillary molar teeth were collected. The specimens with any sign of crack, restoration, caries, fracture, and stain were excluded from the study. Any remaining soft tissues were removed from the tooth surface and the specimens were kept in a $0.1 \%$ thymol suspention $(\mathrm{pH}=7)$ at 4 ${ }^{\circ} \mathrm{C}$ for $30 \mathrm{~d}$. Afterwards, the teeth were washed with running water for $60 \mathrm{sec}$ and gently dried using air spray. Next, they were embedded in cubic acrylic (Acropars, Marlic Medical Co., Tehran, Iran) resin molds to ensure that the occlusal surface was mounted parallel to the acrylic resin and the cementoenamel junction (CEJ) was in the same level as acrylic resin surface. After the complete polymerization of acrylic resin, the occlusal surface of the teeth was sectioned at a depth of $2 \mathrm{~mm}$ from dentinoenamel junction (DEJ), using the D\&Z diamond disk with water cooling to obtain a perfectly smooth dentin surface. The surfaces were polished using 600-grit silicon carbide paper (SiC paper, Piramit, Istanbul, Turkey) under constant water spray to homogenize the surface.

$2.5 \%$ and $1 \%$ Chitosan solution ( $\mathrm{w} / \mathrm{v}$ ) was prepared with $\mathrm{pH} 4.74$ and 3.98 respectively. Then teeth were randomly divided to eight groups $(n=10)$ which were denominated as follows:

Group I: Teeth were etched using a two-step self-etch system (Clearfil SE Bond 2,
Kuraray Co Ltd, Osaka, Japan). Initially, the primer was applied for $20 \mathrm{sec}$ with a microbrush and dried for 5 sec using gentle air flow. Then, two coats of the bonding agent were applied with a microbrush. The specimens were cured using the LED device (Bluelex GT1200, Monitex, Taiwan) with a light intensity of $1200 \mathrm{~mW} / \mathrm{cm}^{2}$ and wavelength of $470 \mathrm{~nm}$ for $10 \mathrm{~s}$.

Group II: Teeth were conditioned with 37\% phosphoric acid (Denfil, Vericom, Korea) for 15 $\mathrm{sec}$ and then rinsed for another $15 \mathrm{sec}$. Spare water was removed by means of a cotton pellet. Then, a two-step etch-and-rinse system bonding agent (Adper Single bond 2, 3M ESPE, USA) was implemented in two coats for $15 \mathrm{sec}$, using a microbrush and the solvent was vaporized via 5 -sec gentle air flow. The specimens were then light-cured for $10 \mathrm{sec}$.

Group III: Teeth were treated with $2.5 \%$ chitosan solution [17] for 60 sec using a microbrush and then washed with water for 20 sec. Then, a two-step self-etch adhesive system was applied as described in group I.

Group IV: Teeth were treated with $2.5 \%$ chitosan solution for $60 \mathrm{sec}$ and then rinsed with water for $20 \mathrm{sec}$. Then the teeth were conditioned using 37\% phosphoric acid for 15 $\mathrm{sec}$ and washed with water for $20 \mathrm{sec}$, followed by a two-step etch-and-rinse system as described in group II. 
Group V: 37\% phosphoric acid was used to etch teeth for $15 \mathrm{sec}$ and then the specimens were rinsed with water for $20 \mathrm{sec}$. The teeth surfaces were treated with $2.5 \%$ chitosan for $60 \mathrm{sec}$ and then washed with water for $20 \mathrm{sec}$, followed by a two-step etch-and- rinse system used in a process same as group II.

Group VI: Teeth were treated with $1 \%$ chitosan solution [19] for $60 \mathrm{sec}$ and then washed with water for $20 \mathrm{sec}$. Then, a two-step self-etch adhesive system was implemented as described in group I.

Group VII: The teeth were treated with $1 \%$ chitosan solution for $60 \mathrm{sec}$ and then rinsed with water for $20 \mathrm{sec}$. Then, the teeth were conditioned using 37\% phosphoric acid for 15 sec and washed with water for $20 \mathrm{sec}$, followed by a two-step etch-and-rinse bonding system as per group II.

Group VIII: Etching was performed using $37 \%$ phosphoric acid for 15 sec. Teeth were then rinsed with water for $20 \mathrm{sec}$. Afterwards, the specimens were treated with $1 \%$ chitosan for $60 \mathrm{sec}$ and then washed with water for 20 sec, followed by a two-step etch \& rinse system used the same way as mentioned in group II.

Clear plastic molds with $3 \mathrm{~mm}$ height and $2 \mathrm{~mm}$ internal diameter were placed on the prepared surfaces and were filled with a nanohybrid composite (Z350, A2 Shade, 3M ESPE, USA). The resin composite was cured for $40 \mathrm{sec}$. The distance between the composite and the light curing unit tip was less than $1 \mathrm{~mm}$. A scalpel (Juya, Iran) was used to remove the excess material. Plastic molds were then lightly removed from the composite using the scalpel.

The teeth were dipped in distilled water for $24 \mathrm{~h}$ at room temperature $\left(25^{\circ} \mathrm{C}\right)$. All the samples were then subjected to the shear bond strength test with a shear Knife-edge testing apparatus in a universal testing machine (Zwick/ Roell Z020, Germany) at a crosshead speed of $1.0 \mathrm{~mm} / \mathrm{min}$. The active tip of the machine was placed close to the test specimens so that the shear strength force was directed toward the bonded area. The force was recorded in Newton and the SBS values were measured from the maximum failure load divided by the surface area in megapascals (MPa).

\section{Mode of failure}

The failure modes were inspected using a stereomicroscope (BestScope, BS-3060C, China) at 40x magnification. The modes of failure were grouped as: adhesive failure, cohesive failure in composite, cohesive failure in dentine, or mixed failure when both occurred in one fracture surface (Figure 1) [20].
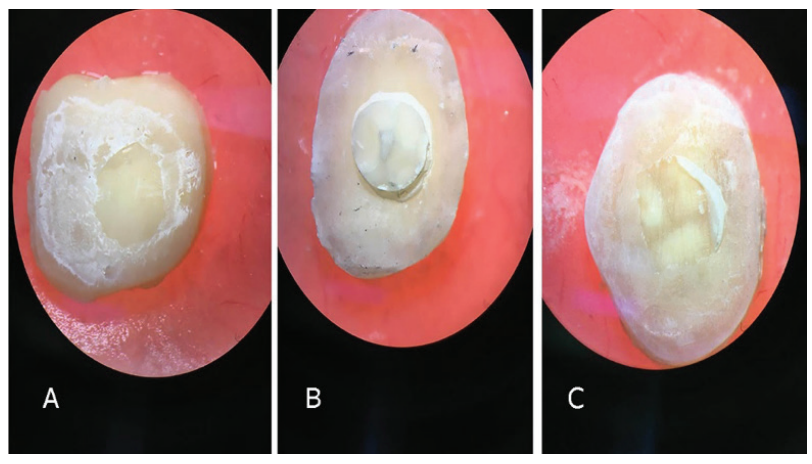

Figure 1 - Stereomicroscope $(\times 40)$ of the debonded surface: (A) Adhesive failure, (B) Cohesive failure in composite, (C) Mixed failure.

\section{Statistical analysis}

The SPSS software, version 18 for Windows (SPSS Inc., Chicago, IL, USA) was used to analyze data. The Kolmogorov-Smirnov test was employed to assess normality assumption. Two-way ANOVA was applied to find interaction between type of adhesive system and chitosan pretreatment.

One-way ANOVA and post-hoc Tukey's tests were used to detect significant differences in subgroup comparisons. Moreover, independent $t$ test was applied to observe the differences in SBS values between chitosan applied before and after the etching process in etch-and-rinse groups. The level of significance was considered as $\mathrm{p} \leq 0.05$. 


\section{RESULTS}

The normality assumption was observed in all groups. Two-way ANOVA showed a significant interaction effect between the type of adhesive system and chitosan pretreatment $(\mathrm{p}<0.001)$ (Figure 2). Mean and standard deviations of SBS values $(\mathrm{MPa})$ in different experimental groups are given in Table II.

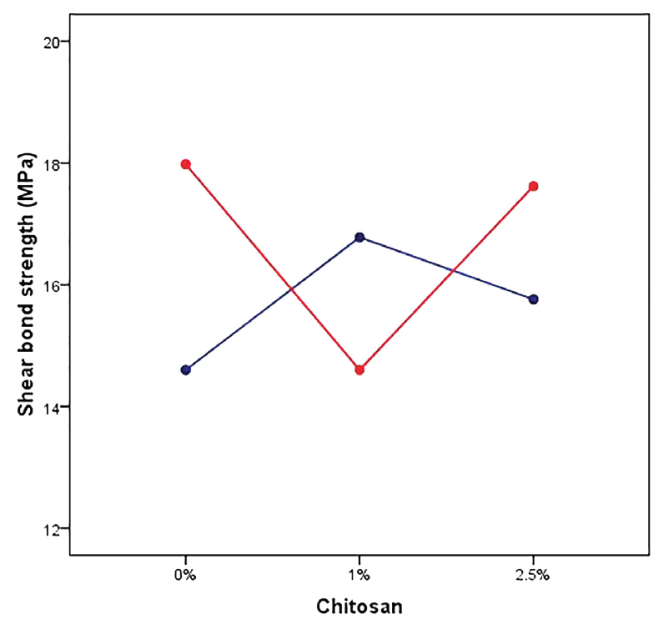

Bonding 二 $\mathrm{SE}$

Figure 2 - Line diagram representing the SBS values of all experimental groups.

Table II - Mean \pm SD of SBS values (MPa) of different experimental groups

\begin{tabular}{|c|c|c|c|c|}
\hline \multirow{2}{*}{$\begin{array}{l}\text { Adhesive } \\
\text { system }\end{array}$} & \multicolumn{3}{|c|}{ Chitosan concentrations } & \multirow{2}{*}{ Pvalue } \\
\hline & Control & $1 \%$ & $2.5 \%$ & \\
\hline Self-etch & $14.60 \pm 1.09^{\mathrm{B}, \mathrm{b}}$ & $16.78 \pm 1.34^{\mathrm{A}, \mathrm{a}}$ & $15.76 \pm 1.10^{\mathrm{AB}, \mathrm{a}}$ & $0.001^{*}$ \\
\hline Etch-and-rinse & $17.98 \pm 1.77^{\text {Аa }}$ & $14.60 \pm 1.88^{\mathrm{B}, \mathrm{b}}$ & $17.62 \pm 2.62^{\text {Аа }}$ & $0.002^{*}$ \\
\hline Pvalue & $<0.001$ & 0.008 & 0.053 & - \\
\hline
\end{tabular}

-Statistically significant difference*

-Different upper case letters show significant difference between chitosan concentrations in each adhesive system (in a row)

-Different lower case letters show significant difference between adhesive systems in each chitosan concentration (in a column)

For the self-etch groups, a statistically significant difference was detected between the SBS of different chitosan concentrations ( $\mathrm{p}$ $=0.001)$. The highest SBS value among selfetch groups was observed with $1 \%$ chitosan pretreatment (16.78 \pm 1.34) which was significantly greater than the non-pretreated groups $(14.60 \pm 1.09)(\mathrm{p}=0.001)$.

In the etch-and-rinse groups, a significant difference was observed between the SBS of different chitosan concentrations as well ( $\mathrm{p}$ $=0.002)$. The lowest SBS in this group was detected in 1\% chitosan concentration (14.60 \pm 1.88 ), which was significantly lower than $2.5 \%$ chitosan $(17.62 \pm 2.62)$ and non-chitosan pretreated groups $(17.98 \pm 1.71)(\mathrm{p}=0.009$ and $\mathrm{p}=0.004$, respectively).

To compare etch-and-rinse and selfetch groups, the difference in SBS values were insignificant when pretreated with $2.5 \%$ chitosan $(\mathrm{p}=0.053)$. In groups treated with $1 \%$ chitosan, the self-etch system revealed significantly higher SBS values compared to etch-and-rinse bonding system $(p=0.008)$. However, in groups without chitosan pretreatment, etch-and-rinse specimens showed better performance in terms of higher SBS values compared to self-etch $(\mathrm{p}<0.001)$.

According to Table 3, treatment with $1 \%$ chitosan following acid etching led to higher SBS values compared to when the chitosan was applied before etching. The difference was significant in $1 \%$ chitosan concentration ( $p=$ 0.030 ). No statically significant difference was found between the SBS of 2.5\% chitosan applied before or after etching $(\mathrm{p}=0.099)$.

Table III - The results of independent T test on the differences in SBS values between chitosan pretreatments before and after the etching process in etch-and-rinse groups

\begin{tabular}{c|cc|c|}
$\begin{array}{c}\text { Chitosan } \\
\text { concentration }\end{array}$ & \multicolumn{2}{|c|}{ Chitosan treatment sequence } & \multirow{2}{*}{ P value } \\
\cline { 2 - 3 } & Prior to etch & Following etch & \\
\hline $2.5 \%$ & $14.60 \pm 1.09$ & $15.76 \pm 1.10$ & $0.030^{\star}$ \\
\hline & $16.78 \pm 1.34$ & $17.98 \pm 1.71$ & $0.099^{\star}$ \\
\hline
\end{tabular}

Statistically significant difference*

The descriptive statistics of fracture mode of the study groups are shown in Table 4. In all the experimental groups, a predominance of mix fractures was observed in dentin, representing $50 \%$ to $80 \%$ of the failure modes, depending on the pretreatment method and adhesive systems. 
Table IV - Fracture modes of the study groups

\begin{tabular}{|c|c|c|c|}
\hline Groups & Adhesive & $\begin{array}{l}\text { Cohesive } \\
\text { In composite }\end{array}$ & Mix \\
\hline Group I & $10 \%$ & $10 \%$ & $80 \%$ \\
\hline Group II & $10 \%$ & $20 \%$ & $70 \%$ \\
\hline Group III & $20 \%$ & $20 \%$ & $60 \%$ \\
\hline Group IV & $20 \%$ & $10 \%$ & $70 \%$ \\
\hline Group V & $10 \%$ & $30 \%$ & $60 \%$ \\
\hline Group VI & $20 \%$ & $30 \%$ & $50 \%$ \\
\hline Group VII & $30 \%$ & $0 \%$ & $70 \%$ \\
\hline Group VIII & $10 \%$ & $20 \%$ & $70 \%$ \\
\hline
\end{tabular}

- Group I) two-step self-etch system (Clearfil SE bond); II) twostep etch-and-rinse system (Adper single bond 2); III) 2.5\% chitosan + Clearfil SE bond; IV) $2.5 \%$ chitosan +etch + Adper single bond $2 ; \mathrm{V}$ ) etch $+2.5 \%$ chitosan + Adper single bond 2 ; VI) $1 \%$ chitosan + Clearfil SE bond; VII) $1 \%$ chitosan + etch + Adper single bond 2; VIII) etch $+1 \%$ chitosan + Adper single bond 2.

\section{DISCUSSION}

Long-term studies have demonstrated a reduction in the resin-dentin bond strength over time [3]. The dentin-bond challenge is particularly greater in deep dentin due to its reduced intertubular dentin and enlarged tubular diameter [4]. High perviousness of the bonded interface, inadequate resin infusion of dentin collagen, and the initiation of endogenous collagenolytic enzyme activities, such as MMPs are among the factors that can accelerate collagen degradation and thereby, diminish bond durability in deep dentin [21]

Primary etch-and-rinse bonding systems and the less severe forms of self-etch adhesives can activate MMPs through the dentin bonding process [22], which results in a reduced bond durability [9]. Therefore, surface treatment with an agent that can impede MMPs could be advantageous in improving the bond strength [11]. In the present study, we investigated the SBS of deep dentin to etch-and-rinse and self-etch adhesive modes using various concentrations of chitosan in an attempt to improve the bond strength. The shear bond test arrangement is a regular in-vitro method to examine dental adhesives for resinbased restorations. Therefore, in the present study the shear bond test was implemented to assess the bond strength owing to its ease of use, and minimum requirement of equipment or specimen preparation [23].

Chitosan, which is a biopolyaminosaccharide derived from alkaline deacetylation of chitin, has free reactive groups that interact with the produced chemical links and collagen [24]. The dentin collagen incorporated with chitosan has shown resistance to degradation by bacterial collagenase [12]. Moreover, the chitosan amino groups seize the hydrogen ions creating positive charges leading to bioadhesive capability against the negatively charged substrates such as collagen [25]. It has been shown that different concentrations of chitosan can eliminate or modify smear layer by removing the inorganic content of dentin smear layer, thus, resulting in enhanced bond durability [14]. While chitosan is insoluble in $\mathrm{pH}$ higher than 7 , it is significantly soluble in acidic $\mathrm{pH}$ and diluted acids such as lactic acid, acetic acid, and formic acid, thereby, affecting its substrate $[26,27]$. The higher the concentration of chitosan gets, the greater the consumption of $\mathrm{H}+$ following free amino group protonation, thus leading to increased $\mathrm{pH}$ [28].

According to our findings, pretreatment with chitosan led to an increase in the SBS of the self-etch groups, with the increase being significant for $1 \%$ chitosan concentration. The improvement in the SBS of specimens treated with chitosan can be attributed to its resistance against degradation by bacterial collagenase. Moreover, chitosan has acidic $\mathrm{pH}$ which might contribute to an increase in bond strength of the self-etch group to dentin. Thus, in the self-etch group, the significantly greater bond strength of 1\% chitosan compared to $2.5 \%$ chitosan could be due to its more acidic $\mathrm{pH}(\mathrm{pH}=3.98$ for $1 \%$ compared to $\mathrm{pH}=4.74$ for $2.5 \%)$. This finding is in line with the results of Mohamed et al.[29] which showed that lower concentration of chitosan $(0.2 \%)$ had higher microtensile bond strength to dentin compared to higher chitosan concentration (2.5\%).

In contrast to the self-etch groups, our findings showed that the application of $1 \%$ chitosan 
significantly reduced the SBS of composite to deep dentin in the etch-and-rinse groups when chitosan was applied prior to acid etch. The findings of the present study also showed that although the application of $1 \%$ chitosan after the phosphoric acid was able to significantly enhance the bond strength compared to when it was applied before etching, its bond strength was still inferior to the control group.

Our findings on the etch-and-rinse groups were in line with the findings of Elsaka [19] who reported that the application of $0.5 \%$ and $1 \%$ chitosan resulted in reduced bond strength values. Furthermore, Szczepanska et al. [18] confirmed a compromised bond strength to dentin when a formulated two-step etch-and-rinse adhesive system was modified with chitosan.

Significant reduction in the bond strength figures detected in the etch-and-rinse specimens that were primarily treated with $1 \%$ chitosan can be explicated by the retention and accumulation of chitosan inside the collagen fibrils network. This could lead to the eradication of the interfibrillar spaces, by inhibiting the penetration of phosphoric acid and consequently, reduced acid etch efficiency. As shown by previous studies, open interfibrillar spaces and accurate infiltration of resin to the intertubular dentin collagen network are required to form a hybrid layer, which is essential for effective dentin bonding [13]. Thus, a reducing gradient of resin monomer dissemination within the chitosan pretreated etched dentin in etch-andrinse systems might form deficiently infiltrated sites and uncovered collagen fibrils at the lowermost of the hybrid layer, leading to reduced bond strength [30]. Improved bond strength following the application of $1 \%$ chitosan after etching process could be ascribed to the ability of chitosan to form fibrillar arrangement within the protein matrix, leading to improved degradation resistance and mechanical properties. Chitosan may have an effect on opening interfibrillar spaces, resin infiltration, as well as hybrid layer formation [29].

Our findings also revealed that $2.5 \%$ chitosan had no significant influence on the shear bond strength in etch-and-rinse groups; whether applied before or after the etching process.
Furthermore, according to our findings, significant differences were observed in the SBS values between the self-etch and etch-and-rinse bonding systems. Etch-and-rinse adhesives had significantly greater bond strength when no pretreatment was performed on the specimens. Previous studies confirm the results attained in the present investigation on non-pretreated dentin, showing higher bond strength to dentin for etch-and-rinse adhesive systems compared to self-etch ones. Etch-and-rinse bonding system has a separate etching phase which eliminates the mineral contents of dentin to a depth of 5-8 $\mu$, increasing dentin permeability and infiltration of adhesive monomers [31]. The greater SBS of the etch-and-rinse bonding system can be attributed to the fact that higher micro-retentive surface is acquired when the tooth is conditioned, using phosphoric acid as compared to when the tooth is etched by the self-etch adhesive systems [6]. Moreover, etching with phosphoric acid in etchand-rinse adhesives leads to the creation of lengthy thicker resin tags in comparison with the self-etch adhesive systems [32].

On the contrary, the findings of the current study demonstrated that when dentin was pretreated with 1\% chitosan, self-etch adhesives showed significantly greater bond strength compared to etch-and-rinse. This finding can in fact confirm and emphasize that $1 \%$ chitosan pretreatment could only efficiently influence the self-etch bonding systems.

In all the experimental groups, the predomination of mix fractures was noticed in dentin, representing 50 to $80 \%$ of the failure modes. An increase in cohesive fractures in resin was detected in the present study when chitosan was applied after the acid etching process. Moreover, the failure mode differences between etch-andrinse and self-etch groups varied depending on the prior pretreatment. When no pretreatment was applied, the cohesive failures were greater in etch-and-rinse system; however, with chitosan pretreatment, the cohesive failures were greater in the self-etch groups.

Additionally, in self-etch groups, an increase in cohesive failure was observed with increased 
chitosan concentration. Conversely, with etch-andrinse adhesives, our findings revealed an inverse relation between the chitosan concentration and the cohesive failures.

Finally, as the results of this study indicates, ideal results for the improved dentin bond strength can be achieved through immediate dentin pretreatment with $1 \%$ chitosan in self-etch adhesive systems. The pretreatment of surface with chitosan may not be advantageous for etchand-rinse bonding systems.

The present study was conducted in a laboratory setting; hence we could not simulate the oral environment precisely. Therefore, further clinical studies are required to substantiate our findings. Moreover, the future of chitosan pretreatment still requires further investigations in terms of its effect on other properties of resin restorations such as their mechanical strength and physical properties. Further, the effect of aging on the bond strength of chitosan treated dentin along the application of acetic acid as a control group is recommended to be evaluated in future studies.

\section{CONCLUSION}

Improved dentin bond strength can be achieved through immediate dentin pretreatment with $1 \%$ chitosan in self-etch adhesive systems. Hence, it can be recommended as an efficient chairside technique to improve the SBS of resin composite to dentin. The pretreatment of surface with chitosan may not be advantageous for etchand-rinse adhesive systems in terms of increasing bond strength.

\section{Acknowledgment}

The authors thank the Vice-Chancellery of Shiraz University of Medical Science for supporting this research (Grant \#19615). The authors also thank Dr. Vossoughi of the Dental Research Development Center of Shiraz School of Dentistry for the statistical analysis and Mrs. Bagheri from Biomaterials Research Center for experimental tests. The authors wish to thank Mr. H. Argasi at the Research Consultation Center (RCC) of Shiraz University of Medical Sciences for his invaluable assistance in editing this manuscript.

\section{Conflict of interest}

None

\section{REFERENCES}

1. Lynch CD, Frazier KB, McConnell RJ, Blum IR, Wilson NH. Minimally invasive management of dental caries: contemporary teaching of posterior resinbased composite placement in US and Canadian dental schools. J Am Dent Assoc. 2011;142(6):612-20. doi:10.14219/jada.archive.2011.0243.

2. Akbarian S, Sharafeddin F, Akbarian G. Evaluation of the influence of three different temperatures on microleakage of two self-etch and one total-etch adhesives. J Contemp Dent Pract. 2015;16(3):178-82. doi: 10.5005/ jp-journals-10024-1657.

3. Mohammed Hassan A, Ali Goda A, Baroudi K. The effect of different disinfecting agents on bond strength of resin composites. Int J Dent 2014:2014. doi: 10.1155/2014/231235

4. Kinney J, Balooch M, Marshall S, Marshall Jr G, Weihs T. Atomic force microscope measurements of the hardness and elasticity of peritubular and intertubular human dentin. JBiomech Eng. 1996;118:133-5. doi: 10.1115/1.2795939

5. Yesilyurt C, Bulucu B. Bond strength of total-etch and self-etch dentin adhesive systems on peripheral and central dentinal tissue: a microtensile bond strength test. J Contemp Dent Pract. 2006;7(2):26-36.

6. Ceballos L, Camejo DG, Fuentes MV, Osorio R, Toledano M, Carvalho RM, et al. Microtensile bond strength of total-etch and self-etching adhesives to caries-affected dentine. J Dent. 2003:31(7):469-77. doi:10.1016/s03005712(03)00088-5

7. Hamouda IM, Samra NR, Badawi MF. Microtensile bond strength of etch and rinse versus self-etch adhesive systems. J Mech Behav Biomed Mater 2011;4(3):461-6. doi:10.1016/j.jmbbm.2010.12.007

8. Bin-Shuwaish MS. Effects and effectiveness of cavity disinfectants in operative dentistry: a literature review. J Contemp Dent Pract. 2016;17(10):867-79. doi: 10.5005/jp-journals-10024-1946

9. Deng D, Huang X, Huang C, Yang T, Du X, Wang Y, et al. Effects of chlorhexidine on bonding durability of different adhesive systems using a novel thermocycling method. Aust Dent J. 2013;58(2):148-55. doi.org/10.1111/ adj.12038

10. Bedran-Russo AKB, Pereira PN, Duarte WR, Drummond JL, Yamauchi M. Application of crosslinkers to dentin collagen enhances the ultimate tensile strength. J Biomed Mater Res. 2007;80(1):268-72. doi: 10.1002/jbm.b.30593

11. André CB, Gomes BPFA, Duque TM, Stipp RN, Chan DCN, Ambrosano GMB, et al. Dentine bond strength and antimicrobial activity evaluation of adhesive systems. J Dent. 2015;43(4):466-75. doi: 10.1016/j.jdent.2015.01.004

12. Shrestha A, Friedman S, Kishen A. Photodynamically crosslinked and chitosan-incorporated dentin collagen. J Dent Res. 2011;90(11):1346-51. doi: 10.1177/0022034511421928

13. Petri DF, Donegá J, Benassi AM, Bocangel JA. Preliminary study on chitosan modified glass ionomer restoratives. Dent Mater. 2007;23(8):1004-10. doi: 10.1016/j.dental.2006.06.038.

14. Del Carpio-Perochena A, Bramante CM, Duarte MAH, de Moura MR, Aouada FA, Kishen A. Chelating and antibacterial properties of chitosan nanoparticles on dentin. Restor Dent Endod. 2015;40(3):195-201. doi: 10.5395/rde.2015.40.3.195 
15. Ren Q,LiZ, Ding L, Wang X, Niu Y, Qin X, etal. Anti-biofilm and remineralization effects of chitosan hydrogel containing amelogenin-derived peptide on initial caries lesions. Regen Biomater. 2018;5(2):69-76. doi: 10.1093/rb/rby005

16. GuL, Cai X, Guo J,Pashley D, Breschi L, Xu H, et al. Chitosan-based extrafibrillar demineralization for dentin bonding. J Dent Res. 2019;98(2):18693. doi: 10.1177/0022034518805419

17. Curylofo-Zotti FA, Scheffel DLS, Macedo AP, de Souza-Gabriel AE, Hebling J Corona SAM. Effect of Er: YAG laser irradiation and chitosan biomodification on the stability of resin/demineralized bovine dentin bond. J Mech Behav Biomed Mater.2019;91:220-8. doi:10.1016/j.jmbbm.2018.12.022

18. Szczepanska J, Pawlowska E, Synowiec E, Czarny P, Rekas M, Blasiak J, et al. Protective effect of chitosan oligosaccharide lactate against DNA doublestrand breaks induced by a model methacrylate dental adhesive. Med Sci Mon Int Med J Exp Clin Res. 2011;17(8):201-8. doi: 10.12659/MSM.881898

19. Elsaka SE. Antibacterial activity and adhesive properties of a chitosancontaining dental adhesive. Quintessence Int. 2012;43(7):603-13.

20. Ugurlu M. Effect of the double application of universal adhesives on the dentine bond strength after radiotherapy. Aust Dent J.2020. doi.org/10.1111/ adj.12744

21. Frassetto A, Breschi L, Turco G, Marchesi G, Di Lenarda R, Tay FR, et al. Mechanisms of degradation of the hybrid layer in adhesive dentistry and therapeutic agents to improve bond durability-A literature review. Dent Mater. 2016;32(2):41-53. doi: 10.1016/j.dental.2015.11.007

22. Zhou JTJ, Yang X, Cheng C, Wang X, Chen L. Effect of Chlorhexidine Application in a Self-etching Adhesive on the Immediate Resin-Dentin Bond Strength. J Adhes Dent 2010:12: 27-31. doi: 10.3290/j.jad.a17543

23. Aguilera FS, Osorio R, Osorio E, Moura P, Toledano M. Bonding efficacy of an acetone/based etch-and-rinse adhesive after dentin deproteinization. Med Oral Patol Oral Cir Bucal. 2012;17(4):649-54. doi: 10.4317/medoral.17717
24. Kishen A, Shrestha S, Shrestha A, Cheng C, Goh C. Characterizing the collagen stabilizing effect of crosslinked chitosan nanoparticles against collagenase degradation. Dent Mater. 2016;32(8):968-77. doi: 10.1016/j. dental.2016.05.005

25. Arnaud TMS, de Barros Neto B, Diniz FB. Chitosan effect on dental enamel de-remineralization: an in vitro evaluation. J Dent. 2010;38(11):848-52. doi: 10.1016/j.jdent.2010.06.004

26. Kmiec M, Pighinelli L, Tedesco M, Silva M, Reis V. Chitosan-properties and applications in dentistry. Adv Tissue Eng Regen Med Open Access. 2017:2(4):00035. doi:10.15406/atroa.2017.02.00035

27. Nunes RA de C, Amaral FLB do, França FMG, Turssi CP, Basting RT.Chitosan in different concentrations added to a two-step etch-and-rinse adhesive system: influence on bond strength to dentin. Braz Dent Sci. 2017;20(4):5562. doi: 10.14295/bds.2017.v20i4.1461

28. Liu W, Wu WD, Selomulya C, Chen XD. Uniform chitosan microparticles prepared by a novel spray-drying technique. Int J Chem Eng. 2011;2011. doi. org/10.1155/2011/267218

29. Mohamed AM, Nabih SM, Wakwak MA. Effect of chitosan nanoparticles on microtensile bond strength of resin composite to dentin: an in vitro study. Braz Dent Sci. 2020;23(2):10. doi: 10.14295/bds.2020.v23i2.1902

30. Stanislawczuk R, Amaral R, Zander-Grande C, Gagler D, Reis A, Loguercio A Chlorhexidine-containing acid conditioner preserves the longevity of resindentin bonds. Oper Dent. 2009;34(4):481-90. doi:10.2341/08-016-L

31. Sharafeddin F, Safari M. Effect of papain and bromelain enzymes on shear bond strength of composite to superficial dentin in different adhesive systems. J Contemp Dent Pract. 2019;20(9):1078. doi:10.5005/ jp-journals-10024-2646

32. Pashley DH, Tay FR, Breschi L, Tjäderhane L, Carvalho RM, Carrilho M, et al. State of the art etch-and-rinse adhesives. Dent Mater. 2011;27(1):1-16. doi: 10.1016/j.dental.2010.10.016

\section{Farahnaz Sharafeddin} (Corresponding address)

Department of Operative Dentistry, Biomaterials Research Center, School of Dentistry, Shiraz University of Medical Sciences.

Email: sharafedinf@yahoo.com

Date submitted: 2020 Aug 16

Accept submission: 2020 Sep 29 